UDC 678.743.22:746.222-139

V.Ye. Levytskyi ${ }^{a, b}$, D.S. Katruk ${ }^{a}$, A.S. Masyuk ${ }^{a}$, U.V. Khromiak ${ }^{c}$

\title{
POLY(VINYL CHLORIDE) PLASTICATES MODIFIED BY POLYSTYRENE: FEATURES OF PREPARATION, MORPHOLOGY AND PROPERTIES
}

\author{
${ }^{a}$ Lviv Polytechnic National University, Lviv, Ukraine \\ b The John Paul II Catholic University of Lublin, Lublin, Poland \\ ${ }^{c}$ Lviv State University of Life Safety, Lviv, Ukraine
}

\begin{abstract}
The influence of component composition and the nature of plasticizer on the features of intermolecular interactions in the system poly(vinyl chloride)-polystyrene-diester phthalate was established. It was found that polystyrene macromolecules are actively involved in interactions with both poly(vinyl chloride) macromolecules and plasticizer molecules, forming associates of slightly smaller size. It was noted that the wetting angle of the surface by plasticizer and the work of adhesion largely depend on the nature of a plasticizer and a polymer dissolved in it. This indicates a significant effect of the nature and content of the polymer modifier on the compatibility of poly(vinyl chloride) and plasticizer and changes in thermodynamic characteristics of the system. The influence of the nature and content of polystyrene modifier on physicochemical features of the migration process of diester phthalate plasticizer from modified poly(vinyl chloride) plasticate as well as on its morphological features was studied. It was found that the thermodynamic compatibility of the components is significantly affected by the wettability of the surface of fine polymer particles with liquid plasticizers, which, in turn, affects the release (migration) of the plasticizer from poly(vinyl chloride) plastics during operation of products based on them. Pre-dissolution of suspension polystyrene or acrylonitrile butadiene styrene plastic in the plasticizer, regardless of its nature, leads to a significant reduction in the value of migration.
\end{abstract}

Keywords: poly(vinyl chloride), modification, migration, plasticization, compatibility parameter, polystyrene.

DOI: $10.32434 / 0321-4095-2022-140-1-68-75$

\section{Introduction}

Today, materials based on plasticized poly(vinyl chloride) (PVC) are widely used in various industries [1]. The following substances are often used as plasticizers for PVC: esters of phthalic acid (about $80 \%$ of the total), adipine esters (5\%), trimelite esters (2\%), phosphate esters (1.5\%), sebacine esters (3\%), epoxy (3\%) and polymeric plasticizers (2\%) [2].

However, during operation under different conditions of products made of PVC plasticized by diesters of phthalic acid, the release of plasticizer from the volume of the material is observed, which leads to a change in the component composition of the material and thus to a change in physicalmechanical and thermophysical properties. At the same time, fragility increases, internal stresses appear and the linear dimensions of the product decrease [3]. The release of the plasticizer has a negative effect in terms of ecology and biosafety.
One of the technological methods of eliminating or significantly reducing this negative impact is the physical modification of such materials by thermoplastics of different nature, which have increased technological compatibility to both poly(vinyl chloride) and a plasticizer [4]. Among the methods of combining PVC with other thermoplastics is an effective method of predissolution of the thermoplastic in the plasticizer with subsequent introduction into the PVC. This method of modification allows achieving the required properties due to the uniform distribution of the dissolved application in the volume of PVC material and its effect on the intermolecular characteristics of the components.

During such modification, increased attention is paid to intermolecular interactions between heterogeneous macromolecules, their thermodynamic and technological compatibility, conformational 
changes of polymers in plasticizer solution as well as the influence of plasticizer nature on other physicochemical characteristics of macromolecules in solution. These factors significantly affect the properties of modified materials and contribute to the expansion of their use [5,6].

When modifying PVC plasticates with modifiers of different nature, special attention is paid to the compatibility of components [7-9]. Quantitative assessment of the compatibility of the components of the polymer-containing system can be obtained based on the assumption that the compression of macromolecules causes their mutual repulsion, and the viscosity of the solution of the polymer blend decreases below the value calculated from the viscosity values of pure components.

In addition, a feature of PVC solutions is molecular aggregation, i.e. the presence in the solution of stable associates of macromolecules. The aggregation in PVC macromolecules in solutions largely depends on the molecular structure of the polymer, the intermolecular interaction of the polymer and the solvent, the nature of a modifier and the concentration of the polymer in solution [10].

An effective method for determining the compatibility of the components of a polymercontaining system is a viscometric method based on determining the viscosity of the system.

\section{Materials and methods}

The samples were prepared via the mixing of Lacovyl PB1156 brand PVC with pre-dissolved polystyrene plastic (suspension polystyrene (SPS)) or impact-resistant polystyrene (HIPS) and acrylonitrile butadiene styrene plastic (ABS). Purified dibutyl phthalate (DBP), dioctyl phthalate (DOP) and diisononyl phthalate (DINP) were used as solvents.

Samples of plasticized material were obtained based on PVC, which was modified with polystyrene plastics. Dissolution of the polystyrene modifier was carried out at a temperature of $373 \mathrm{~K}$ for 1 hour. After dissolution, the resulting solution of polystyrene modifier in the plasticizer was combined with PVC and performed gelation and swelling of PVC plastic at a temperature of $363 \mathrm{~K}$ or $403 \mathrm{~K}$ for 40 minutes.

The degree of release of the plasticizer was evaluated by the difference in weight of plasticized PVC materials using an air thermostat type TVL-K. The samples were kept between strips of filter paper at a temperature of $363 \mathrm{~K}$ for $24 \mathrm{~h}$ and weighed every $30 \mathrm{~min}$. The thickness of the sample was 1 $\mathrm{mm}$.

Viscosimetric studies of polymer solutions in the plasticizer were performed using a viscometer VPZh-2 in accordance with ISO 1628-1:2021. Based on the conducted viscometric researches, the quantitative indicator of compatibility of polymers $\Delta \mathrm{b}$ in the investigated systems was calculated according to refs. [11,12].

Wetting of the PVC surface by plasticizer was determined by the wetting angle (drip method). The wetting angle $\theta$ (or $\cos \theta$ ) was defined as the angle between the tangent drawn to the surface of the liquid droplet and the surface of the solid.

The SPECORD 70 spectrograph was applied for FTIR spectroscopy; the spectra were recorded within the range of $400-4000 \mathrm{~cm}^{-1}$. Samples were prepared by pressing tablets with $\mathrm{KBr}$.

SEM studies were performed applying a REMMA 102-02 scanning electron microscope. The sample surface was scanned using an electron beam with a diameter of several nanometers and an electron energy of $0.2-40 \mathrm{kV}$. Zoom change range 10-30000, the resolution is about $5 \mathrm{~nm}$. Research was conducted on material with a conductive coating.

\section{Results and discussion}

In the course of plasticization of PVC by diesters of phthalic acid, in particular dibutyl phthalate and dioctyl phthalate, the crucial role is played by the phenomena associated with the thermodynamic compatibility of components, which can be characterized to some extent by wetting the surface of fine polymer particles. It should be noted that these factors significantly affect the release (migration) of the plasticizer from poly(vinyl chloride) plastics during the use of products based on them.

Quantitative assessment of the compatibility of the polymer-containing ternary system, in particular poly(vinyl chloride)-polymer modifier-plasticizer, is based on the assumption that the convergence of macromolecules causes their mutual repulsion. In this case, the viscosity value of the polymer mixture solution is reduced below the value calculated according to the viscosity values of the pure components according to the principle of additivity. At the same time, if there is an interaction between the polymers, the associates of both types of macromolecules are formed and the viscosity increases.

Figure 1 shows the dependence of the compatibility parameter $\Delta \mathrm{b}$ on the concentration of polymers in solution, their ratio and the nature of the plasticizer.

The most noticeable interactions in the PVCPS-plasticizer system are observed at low concentrations of polymers in the plasticizer solution

Poly(vinyl chloride) plasticates modified by polystyrene: features of preparation, morphology and properties 


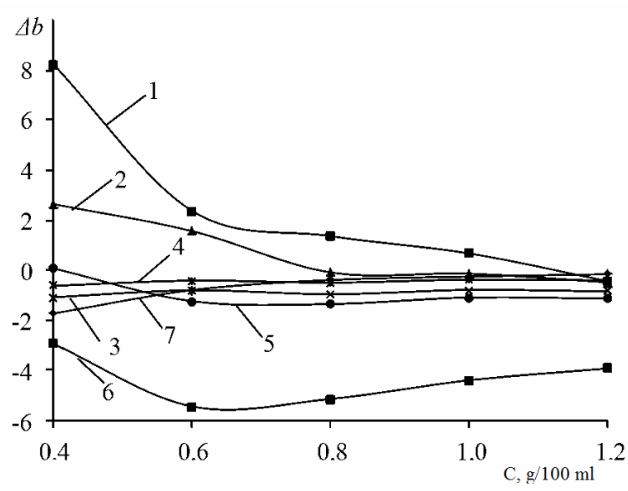

Fig. 1 . The dependence of the compatibility parameter $\Delta \mathrm{b}$ on the concentration of polymers in the system

PVC-SPS-plasticizer, their ratio and the nature of the

plasticizer: 1-6 - DOP; $7-$ DBP. The ratio of polymers

PVC:SPS (parts by weight): $1-95: 5 ; 2-90: 10 ; 3,7-80: 20$;

$$
4-50: 50 ; 5-20: 80 ; 6-5: 95
$$

and at insignificant content of one of the polymers relative to the other. Positive values of $\Delta b$ were obtained for compositions characterized by a ratio of PVC to SPS equal to $95: 5$ and 90:10 parts by weight, which indicates the attraction between heterogeneous PVC and SPS macromolecules, the existence of mixed associates, and, consequently, greater compatibility between the components of the system [12]. The nature of the diester phthalate plasticizer does not significantly affect the compatibility of PVC and SPS in solution.

The established dependences of the compatibility parameter $\Delta b$ on the concentration of polymers in solution, their ratio and the nature of the plasticizer and the nature of intermolecular interactions in the system are confirmed by the results of studies concerning the influence of the nature of the plasticizer, the concentration of SPS in solution on the wettability of the PVC surface. The wettability of the poly(vinyl chloride) surface by plasticizer solutions was evaluated by the values of the cosine of the wetting angle $(\cos \theta)$ and the work of adhesion $\left(\mathrm{W}_{\mathrm{a}}\right)$ (Table).

The wettability of the PVC surface with diesterphthalate plasticizers increases in the following sequence of plasticizers: DINP-DBP-DOP, as evidenced by an increase in the value of adhesion from 56.9 to $61.7 \mathrm{~mJ} / \mathrm{m}^{2}$. The use of a mixture of plasticizers leads to averaging the value of the wetting angle and the work of adhesion.

As can be seen, the wetting angle of the PVC surface by plasticizer and the work of adhesion $\mathrm{W}_{\mathrm{a}}$ largely depend on the nature of the plasticizer and the polymer dissolved in it.

It should be noted that the value of wettability
Wettability of poly(vinyl chloride) surface with solutions of polymer modifiers in diesterphthalate plasticizers

\begin{tabular}{|c|c|c|c|c|}
\hline \multirow{2}{*}{ Plasticizers } & \multicolumn{2}{|c|}{ Modifier,\% } & \multirow{2}{*}{$\cos \theta$} & \multirow{2}{*}{$\begin{array}{l}\text { The work of adhesion } \\
\mathrm{W}_{a}, \mathrm{~mJ} / \mathrm{m}^{2}\end{array}$} \\
\hline & SPS & ABS & & \\
\hline \multirow{7}{*}{ DBP } & - & - & 0.7254 & 58.66 \\
\hline & 2 & - & 0.8099 & 61.54 \\
\hline & 5 & - & 0.8972 & 64.50 \\
\hline & 10 & - & 0.8359 & 62.42 \\
\hline & - & 2 & 0.7512 & 59.54 \\
\hline & 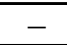 & 5 & 0.9407 & 65.98 \\
\hline & - & 10 & 0.8815 & 63.97 \\
\hline \multirow{4}{*}{ DOP } & - & - & 0.9175 & 61.74 \\
\hline & 2 & - & 0.9790 & 63.72 \\
\hline & 5 & $\begin{array}{c}- \\
\end{array}$ & 0.9264 & 62.03 \\
\hline & 10 & - & 0.9330 & 62.24 \\
\hline DINP & - & - & 0.8340 & 56.85 \\
\hline \multirow{5}{*}{ DBP+DINP } & 2 & - & 0.9079 & 59.14 \\
\hline & 5 & - & 0.9052 & 59.06 \\
\hline & 10 & - & 0.9583 & 60.71 \\
\hline & - & 2 & 0.8077 & 56.04 \\
\hline & - & 5 & 0.7372 & 53.85 \\
\hline
\end{tabular}

of PVC surface by the studied plasticizers increases in the following range of plasticizers: DBP-DOP, as evidenced by the value of the wetting angle of the surface and the value of the work of adhesion. In this case, the use of a mixture of plasticizers (DBP+DINP) leads to averaging of the value of the wetting angle.

With increasing the content of SPS in the solution, the value of the cosine of the wetting angle of the PVC surface appreciably increases. This indicates a significant effect of polystyrene macromolecules on the interfacial characteristics of the PVC-plasticizer system, which is most likely due to the redistribution of intermolecular interactions. It should be noted that the wettability of the PVC surface increases even with increasing the viscosity of the PS solution.

Most likely, this is a consequence of changes in the compatibility of the plasticizer with PVC under the influence of a polymer-modifying additive [13]. The value of the wetting angle of the plasticizer to the PVC surface is reduced with the introduction of a polymeric modifier, in particular a suspension SPS. For plasticizers of linear structure (DBP and DOP), we observed the extreme character of dependence of the wetting angle on the content of SPS in the plasticizer with the minimum values at $1.5-3 \mathrm{wt} . \%$ and 4 to $6 \mathrm{wt} . \%$, respectively.

Slightly different nature of the influence of SPS on the dependence of the wetting angle of the PVC surface was observed with a mixture of plasticizers DBP and DINP on the content of SPS: a significant 
decrease with increasing polymer content was detected, indicating increased compatibility of components in the systems. At the same time, the use of ABS plastic as a polymer modifier leads to an increase in the wetting angle of the PVC surface with a mixture of plasticizers DBP and DINP with increasing the content of the modifier.

With increasing the content of ABS plastic in DBP, a similar effect is observed as in the case of using SPS: the extreme nature of the dependence with minimum values at $4-6$ wt. $\%$ of polymer content. This obviously indicates the same effect of the polymer modifier, regardless of its nature on the compatibility of the components of the PVC systemplasticizer in the case of DBP. Such features of the wetting of the PVC surface with the studied plasticizers indicate a significant effect of the nature and content of the polymer modifier on the compatibility of PVC and plasticizer and, most likely, they are associated with changes in thermodynamic characteristics of the system.

The wettability of the surface increases from more hydrophobic polytetrafluoroethylene to less hydrophobic poly(vinyl chloride), regardless of the nature of the plasticizer (Fig. 2).

The highest value of wettability is observed when using PVC surface and DOP. In this case, the introduction of SPS into the plasticizer contributes to the most significant increase in wettability.

From a rheological point of view, the mixture of polymers can be equated to the dispersion of liquid particles that are deformed. Rheological behavior is

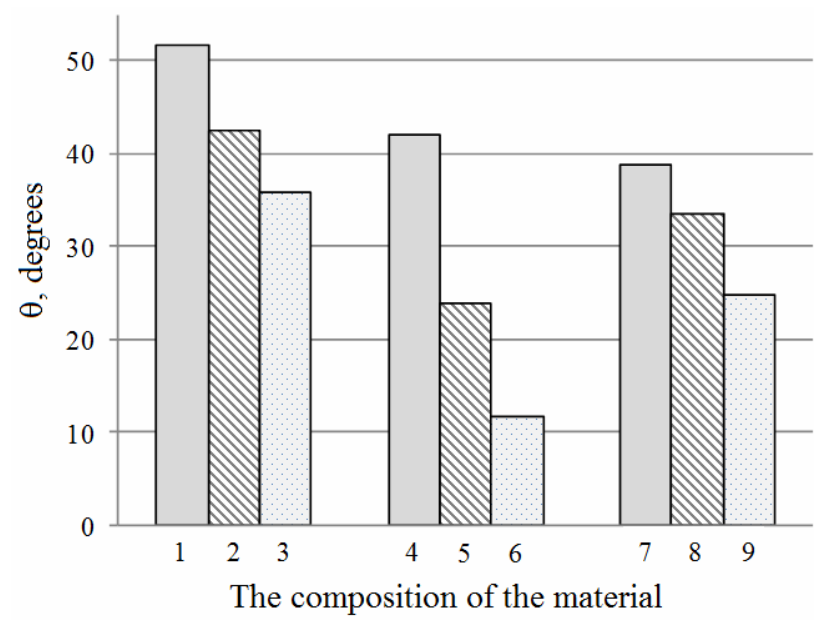

Fig. 2. The influence of the type of base on the wetting angle of the surface with plasticizers: $1-3-$ DBP; 4-6 - DOP;

7, 8 - DINP; 9 - DBP:DINP $=1: 1$.

3, 6 and $9-$ plasticizer contains 2 wt. $\%$ SPS.

Base: 1, 4 and 7 - polytetrafluoroethylene; $2,3,5,6,8$ and $9-\mathrm{PVC}$ determined by the structure of the dispersion, the shape and orientation of the dispersed phase and the interactions between the particles. Compatible flow or extrusion of two polymers, which is an unstable flow in the general case, is sensitive to input conditions. If the interfacial interface is not in the same position at the initial moment, which follows from the ratio of viscosities and relative flow velocity of the two components, it will move very quickly to this position.

Melt flow index (MFI) is a conditional value that characterizes the behavior of a polymer in a viscous state during its processing into products. MFI is used for comparative characterization of raw materials and the choice of method and mode of processing.

The results of the studies of the effect of polystyrene modifier on the MFI of PVC plastic, depending on the gelation temperature of the material and the content of polystyrene modifier, are shown in Fig. 3. An increase in the gelation temperature and the introduction of the SPS modifier leads to an increase in the value of MFI. In this case, it is possible to form a more homogeneous structure with complete decomposition of PVC agglomerates, in the absence of which the fluidity of the melt increases.

The reason for the increase in fluidity and, consequently, the decrease in viscosity may be the inhomogeneous distribution of the concentrations of the components and the appearance of additional free volume localized in the interphase regions during the stratification. Due to the separation mechanism, these areas are characterized by a lower density, i.e. increased free volume. Thus, the reason for the decrease in viscosity may be the formation of a new phase.

An increase in the gelling temperature from $363 \mathrm{~K}$ to $393 \mathrm{~K}$ leads to an increase in the MFI value for unmodified material from 0.65 to $1.6 \mathrm{~g} / 10 \mathrm{~min}$, respectively, and from 1.35 to $2.35 \mathrm{~g} / 10 \mathrm{~min}$, respectively, for modified suspension polystyrene.

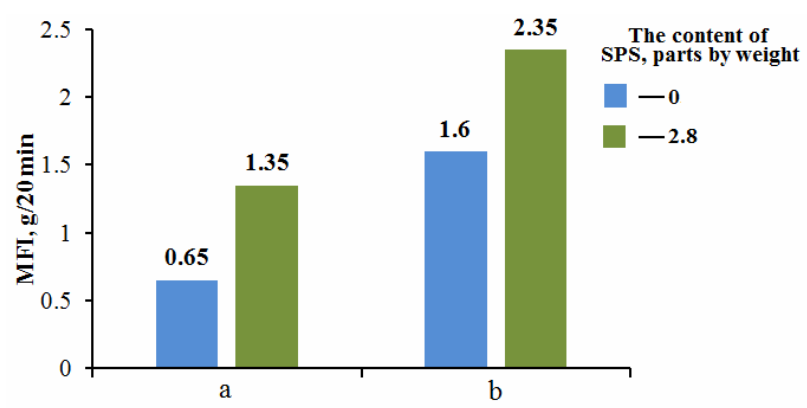

Fig. 3. MFI of modified PVC plastic at different gelation temperatures $(\mathrm{K}): \mathrm{a}-363 ; \mathrm{b}-403$ 
This is obviously a consequence of the formation of a modifier of a more homogeneous structure with the participation of macromolecules with complete decomposition of PVC agglomerates, in the absence of which the melt flow increases.

To detect the influence of the nature of the polystyrene modifier and intermolecular interactions on the morphological changes of PVC plastic, FTIR spectroscopic studies were performed. Figure 4 shows the FTIR spectra of modified PVC polystyrene plastic.

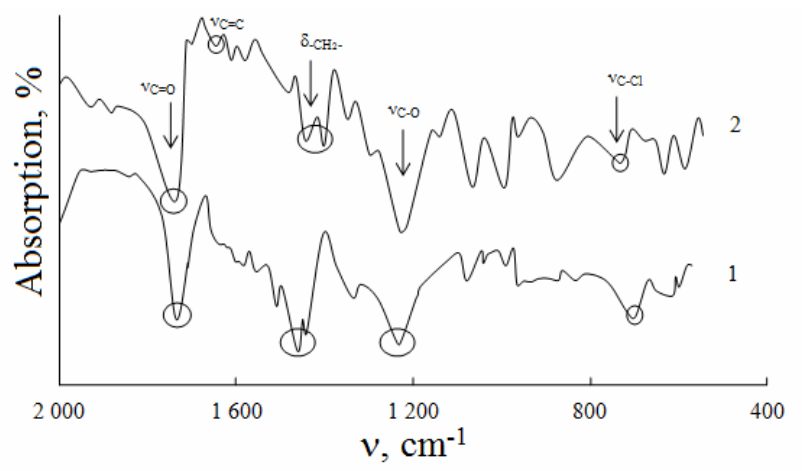

Fig. 4. FTIR spectra of the modified PVC material (PVC:DOP=100:30). Polystyrene modifier ( 2.8 parts by weight): 1 - SPS; 2 - HIPS

Plasticized PVC materials show the absorption bands of the valence vibrations of the $\mathrm{C}=\mathrm{O}$ $\left(1730 \mathrm{~cm}^{-1}\right)$ and $\mathrm{C}-\mathrm{O}\left(1280 \mathrm{~cm}^{-1}\right)$ bonds of the ester group of the plasticizer. Interfacial and intermolecular interactions, in particular between PVC macromolecules and plasticizer, are confirmed by different magnitude of the displacement of the characteristic absorption bands, which correspond to the oscillations of $\mathrm{C}-\mathrm{Cl} \mathrm{PVC}$ macromolecules $\left(1440-1465 \mathrm{~cm}^{-1}\right)$ and $\pi$-electrons of the benzene ring of the plasticizer in the range of $695-735 \mathrm{~cm}^{-1}$, depending on the nature of a modifier [14].

In this case, the PVC hydrogen atom activated by an electronegative chlorine atom located near the adjacent carbon atom is able to participate in
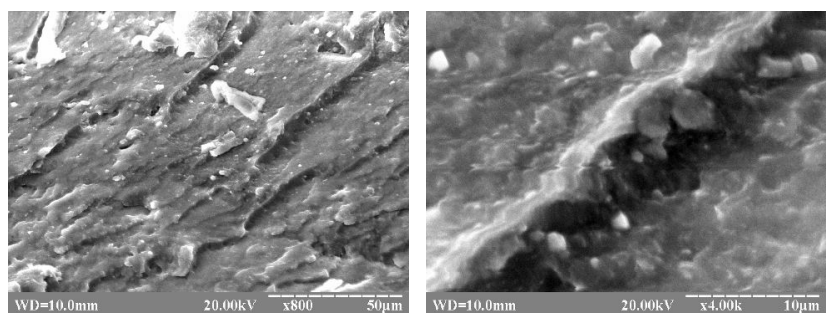

a

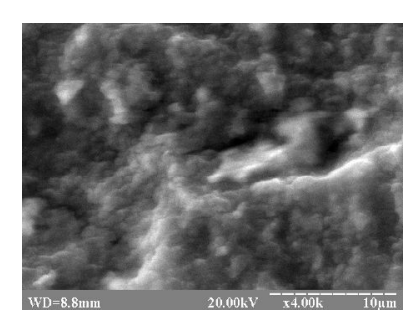

b

Fig. 5. SEM photos of chipped modified PVC material after gelling at $363 \mathrm{~K}$ (PVC:DOP=100:30): a - without modifier; $b$ - SPS as a modifier (2.8 parts by weight)

V.Ye. Levytskyi, D.S. Katruk, A.S. Masyuk, U.V. Khromiak

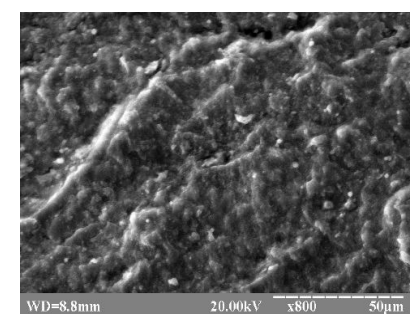

hydrogen bonds. The chlorine atom acts as an electron acceptor, giving them its unfilled 3d-orbitals. The absorption bands of the benzene ring (1440$1600 \mathrm{~cm}^{-1}$ ) correspond to both the SPS and the plasticizer. When used as a HIPS modifier, the absorption bands of $1620-1680 \mathrm{~cm}^{-1}$ correspond to the $\mathrm{C}=\mathrm{C}$ bond of butadiene rubber. The revealed patterns testify to the growth of intermolecular interactions in the PVC-plasticizer system to a greater extent in the presence of SPS than HIPS.

The morphology of PVC plastics, which is largely determined by the compatibility of the components, depends on the nature of the modifier and plasticizer, their content and technological parameters of the processing.

Individual particles can be identified from the SEM photographs, but the predominant presence of agglomerates is obvious (Fig. 5,a), which, swelling in the plasticizer, form a common fluctuation network with macromolecules of polystyrene modifier (Fig. 5,b).

The structure formation in such systems in the gelling process is due to the fact that in the process of phase distribution there are stresses between the phases of the polymer, which have different content of plasticizer.

To establish the influence of the nature of the polymer modifier-suspension polystyrene or acrylonitrile butadiene styrene plastic on the migration of the plasticizer from PVC plastics, studies of the kinetic patterns of release of the plasticizer, depending on its nature, were performed. The results of research to establish the effect of polystyrene modifier on the migration of plasticizer from PVC materials are shown in Fig. 6.

The preliminary dissolution of SPS or ABS plastic in the plasticizer, regardless of its nature, leads to a significant reduction in the value of migration. It should be noted that the lowest values of plasticizer migration are observed in the case of DINP, and the highest are typical of DBP, which is obviously related to both the molecular weight of the plasticizer and its affinity for PVC. 


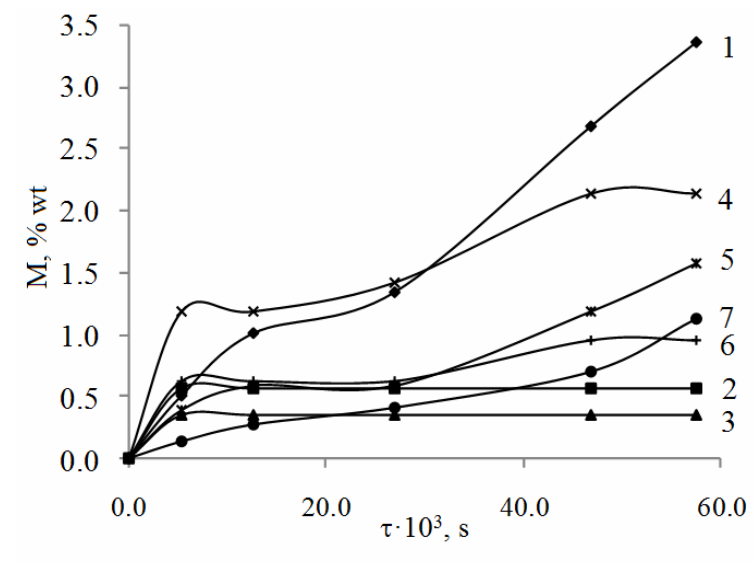

Fig. 6. Kinetics of release of plasticizer from PVC materials depending on the nature of plasticizer: 1, 5, 6- DBP; 2, 7 - DOP; 3 - DINP; 4 - DBP:DINP=1:1; and modifier: $5-\mathrm{ABS}, 6,7-\mathrm{SPS}$. The plasticizer content is

$23 \mathrm{wt} . \%$. The content of the modifier is $2.1 \mathrm{wt} . \%$

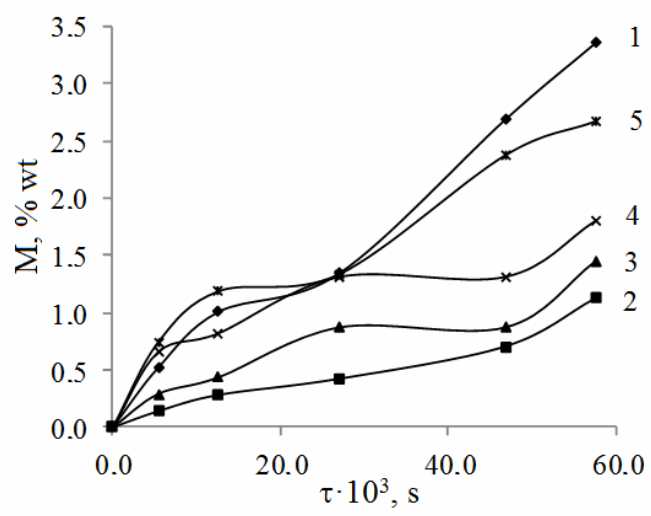

Fig. 7. Kinetics of release of DBP from PVC materials depending on its content: $1-3-23$ wt. $\%$; $4-44$ wt. $\%$;

$5-51 \mathrm{wt} . \%$; and the content of the suspension SPS:

$1-0$ wt. $\% ; 2-2.1$ wt. $\% ; 3-3.1$ wt. $\% ; 4-6.6$ wt.\%; $5-7.4$ wt. $\%$

With increasing the plasticizer content in PVC compositions, the value of its migration increases (Fig. 7). The more plasticizer contained in the composition, the higher is the percentage of its migration.

The limit value of migration is significantly influenced by the nature of the plasticizer and polymer-modifier, which is previously dissolved in it (Fig. 8) as well as the content of the modifier (Fig. 9).

The effect of the polymer-modifier, which is dissolved in the plasticizer, is most pronounced at a higher content of plasticizer in the PVC composition. The decrease in the degree of migration of the plasticizer is obviously a consequence of increasing

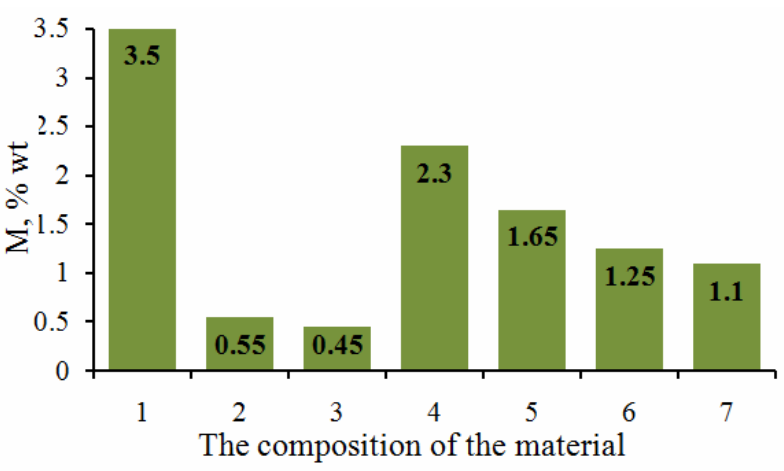

Fig. 8. Limit values of migration of plasticizer from PVC materials depending on the nature of plasticizer:

1, 5, 6 - DBP; 2, 7 - DOP; 3 - DINP; 4 - DBP+DINP; and modifier: $5-\mathrm{ABS} ; 6,7-\mathrm{SPS}$. The plasticizer content is

$23 \mathrm{wt} . \%$. The content of the aircraft is $2.1 \mathrm{wt} . \%$

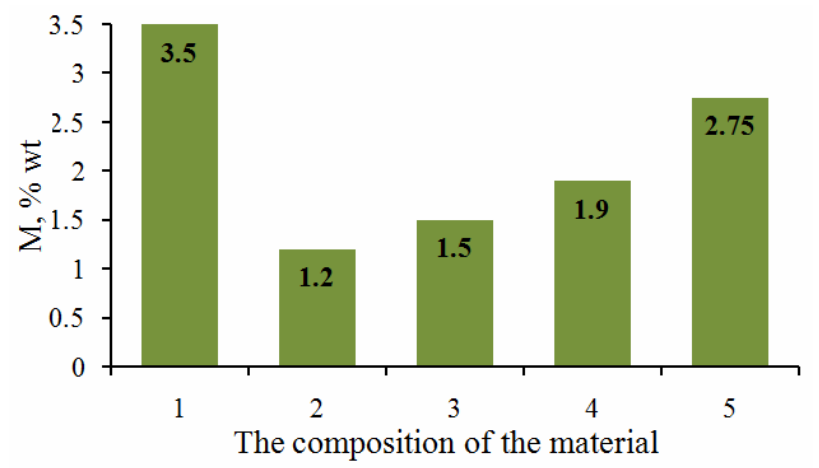

Fig. 9. Influence of SPS on the limit values of DBP migration from PVC plastic. DBP content: $1-3-23$ wt. $\%$;

$4-44$ wt. $\%$; $5-51$ wt. $\%$. The content of SPS: $1-0$ wt. $\%$;

$2-2.1$ wt. $\%$; $3-3.1$ wt. $\%$; $4-6.6$ wt. $\%$; $5-7.4$ wt. $\%$

its compatibility with PVC.

The introduction of polystyrene modifiers into poly(vinyl chloride) plasticized materials can reduce the release of plasticizer from them. The method of introducing the modifier through its preliminary dissolution in the plasticizer, followed by gelation of $\mathrm{PVC}$, is effective.

\section{Conclusions}

It was found that the physical modification of PVC plastics by suspension SPS, which includes predissolution of the modifier in the diester phthalate plasticizer with subsequent combination with PVC, allows distributing evenly the modifier in the volume of material due to increased technological compatibility between components. This effect of the modifier is especially pronounced when the content of SPS in a mixture of PVC is up to $10-15$ parts by weight. This is due to the redistribution of intermolecular interactions in the system PVC-SPS- 
plasticizer. At these ratios, positive values of the compatibility parameter were obtained, which indicates the attraction between heterogeneous PVC and SPS macromolecules and the existence of mixed associates. In this case, the nature of the diester phthalate plasticizer does not significantly affect the compatibility of PVC and SPS in a solution.

A significant effect of polystyrene modifiers on the morphology of poly(vinyl chloride) plastics has been established. There is a shift of the main characteristic absorption bands in the modified poly(vinyl chloride) materials.

It was found that the introduction of polystyrene additives, regardless of the nature of the plasticizer, contributes to a significant reduction in its release from PVC plastics. In particular, the values of the maximum release of plasticizers are reduced by $2-5$ times as compared with the unmodified PVC.

\section{REFERENCES}

1. Patrick S. Practical guide to polyvinyl chloride. Shrewsbury: Rapra Technology Limited, 2005. - 170 p.

2. Wypych G. Handbook of plasticizers. 3rd edition. Elsevier Inc., 2017. -870 p.

3. Effect of additives on flexible PVC foam formation / Demir H., Sipahioglu M., Balkose D., Ulku S. // J. Mater. Process. Technol. - 2008. - Vol.195. - P.144-153.

4. The influence of polystyrene modifier and plasticizer nature on the properties of poly(vinyl chloride) / Levytskyj V., Laruk Y., Humenetsky T., Sikora J. // Chem. Chem. Technol. 2015. - Vol.9. - No. 2. - P.199-203.

5. Physicochemical properties of modified polyesterpolyvinylchloride compositions / Levyts'kyi V.E., Katruk D.S., Shybanova A.M., Bilyi L.M., Humenets'kyi T.V. // Mater. Sci. - 2017. - Vol.52. - No. 4. - P.559-565.

6. Synthesis and properties of adhesive polymermethylmethacrylate materials / Khromiak U., Levytskyi V., Stepova K., Tarnawsky A. // Int. J. Polym. Sci. - 2018. Vol.2018. - Art. No. 4905304.

7. Interaction-structure-property relationships in amorphous polymer blends / Fekete E., Foldes E., Damsits F., Pukanszky B. // Polym Bull. - 2000. - Vol.44. - P.363-370.

8. Influence of modified compacted expanded polystyrene on the rheological properties of polyamide 6 and polystyrene / Moravskyi V.S., Levytskyi V.Ye., Masyuk A.S., Khromiak U.V., // Voprosy Khimii i Khimicheskoi Tekhnologii. - 2019. - No. 1. - P.35-41.
9. Mittal V. Functional polymer blends: synthesis, properties, and performance. - Boca Raton: CRC Press, 2012. $342 \mathrm{p}$.

10. Thakur V.K., Thakur M.K., Рарpu A. Hybrid polymer composite materials: properties and characterization. Cambridge: Woodhead Publishing \& Elsevier, 2017. - 430 p.

11. Krigbaum W.R., Wall F.T. Viscosities of binary polymeric mixtures // J. Polym. Sci. - 1950. - Vol.5. - No. 4. P.505-514.

12. Cragg L.H., Bigelow C.C. The viscosity slope constant k'-ternary systems: polymer-polymer-solvent // J. Polym. Sci. - 1955. - Vol.16. - P.177-191.

13. Unar I.N., Soomro S.A., Aziz S. Effect of various additives on the physical properties of polyvinylchloride resin // Pak. J. Anal. Environ. Chem. - 2010. - Vol.11 - No. 2. - P.44-50.

14. Stuart B. Infrared spectroscopy: fundamentals and applications. - New York: John Wiley \& Sons, 2004. - 203 p.

Received 12.07.2021

\section{ПОЛІВІНІЛХЛОРИДНІ ПЛАСТИКАТИ МОДИФІКОВАНІ ПОЛІСТИРОЛОМ: ОСОБЛИВОСТІ ОДЕРЖАННЯ, МОРФОЛОГІЯ І ВЛАСТИВОСТІ}

\section{В.Є. Левицький, Д.С. Катрук, А.С. Масюк, У.В. Хром'як}

Встановлено вплив компонентного складу і природи пластифікатора на характер міжмолекулярних взаємодій в системі полівінілхлорид-полістирол-діестерфталат. Виявлено, що макромолекули полістиролу беруть активну участь у взаємодіях як з макромолекулами полівінілхлориду, так і молекулами пластифікатора, утворюючи асоціати дещо меншого розміру. Відзначено, що кут змочування пластифікатором полівінілхлоридної поверхні та робота адгезії при цьому значною. мірою залежить від природи пластифікатора та розчиненого в ньому полімеру, що свідчить про суттєвий вплив природи та вмісту полімерного модифікатора на сумісність полівінілхлориду і пластифікатору та зміну термодинамічних характеристик системи. Вивчено вплив природи та вмісту полістирольного модифікатора на фізикохімічні закономірності процесу міграції діестерфталатного пластифікатору із модифікованого полівінілхлоридного пластикату, а також на його морфологічні особливості. Виявлено, що на термодинамічну сумісність компонентів суттєвий вплив має змочуваність поверхні дрібнодисперсних частинок полімеру рідкими пластифікаторами, які, у свою чергу, впливають на вивільнення (мігрування) пластифікатора з полівінілхлоридних пластикатів під час експлуатації виробів на їх основі. Попереднє розчинення суспензійного полістирол- чи акрилонітрилбутадієн-стирольного пластику у пластифікаторі незалежно від його природи призводить до суттєвого зниження значення мігрування.

Ключові слова: полівінілхлорид, модифікування, міграція, пластифікація, параметр сумісності, полістирол. 


\section{POLY(VINYL CHLORIDE) PLASTICATES MODIFIED BY POLYSTYRENE: FEATURES OF PREPARATION, MORPHOLOGY AND PROPERTIES}

\author{
V.Ye. Levytskyi ${ }^{a, b}$, D.S. Katruk ${ }^{a}$, A.S. Masyuk ${ }^{a, ~ ", ~}$ \\ U.V. Khromiak ${ }^{c}$
}

a Lviv Polytechnic National University, Lviv, Ukraine

b The John Paul II Catholic University of Lublin, Lublin, Poland

${ }^{c}$ Lviv State University of Life Safety, Lviv, Ukraine

*e-mail: masyukas@gmail.com

The influence of component composition and the nature of plasticizer on the features of intermolecular interactions in the system poly(vinyl chloride)-polystyrene-diester phthalate was established. It was found that polystyrene macromolecules are actively involved in interactions with both poly(vinyl chloride) macromolecules and plasticizer molecules, forming associates of slightly smaller size. It was noted that the wetting angle of the surface by plasticizer and the work of adhesion largely depend on the nature of a plasticizer and a polymer dissolved in it. This indicates a significant effect of the nature and content of the polymer modifier on the compatibility of poly(vinyl chloride) and plasticizer and changes in thermodynamic characteristics of the system. The influence of the nature and content of polystyrene modifier on physicochemical features of the migration process of diester phthalate plasticizer from modified poly(vinyl chloride) plasticate as well as on its morphological features was studied. It was found that the thermodynamic compatibility of the components is significantly affected by the wettability of the surface of fine polymer particles with liquid plasticizers, which, in turn, affects the release (migration) of the plasticizer from poly(vinyl chloride) plastics during operation of products based on them. Pre-dissolution of suspension polystyrene or acrylonitrile butadiene styrene plastic in the plasticizer, regardless of its nature, leads to a significant reduction in the value of migration.

Keywords: poly(vinyl chloride); modification; migration; plasticization; compatibility parameter; polystyrene.

\section{REFERENCES}

1. Patrick S. Practical guide to polyvinyl chloride. Shrewsbury: Rapra Technology Limited; 2005. 170 p.

2. Wypych G. Handbook of plasticizers. 3rd edition. Elsevier; 2017. $870 \mathrm{p}$

3. Demir H, Sipahioglu M, Balkose D, Ulku S. Effect of additives on flexible PVC foam formation. J Mater Process Technol. 2008; 195: 144-153. doi: 10.1016/j.jmatprotec.2007.04.123.
4. Levytskyj V, Laruk Y, Humenetsky T, Sikora J. The influence of polystyrene modifier and plasticizer nature on the properties of poly(vinyl chloride). Chem Chem Technol. 2015; 9: 199-203. doi: 10.23939/chcht09.02.199.

5. Levyts'kyi VE, Katruk DS, Shybanova AM, Bilyi LM, Humenets'kyi TV. Physicochemical properties of modified polyester-polyvinylchloride compositions. Mater Sci. 2017; 52: 559-565. doi: 10.1007/s11003-017-9990-0.

6. Khromiak U, Levytskyi V, Stepova K, Tarnawsky A. Synthesis and properties of adhesive polymer-methylmethacrylate materials. Int J Polym Sci. 2018; 2018: 4905304. doi: 10.1155/ 2018/490530.

7. Fekete E, Foldes E, Damsits F, Pukanszky B. Interaction-structure-property relationships in amorphous polymer blends. Polym Bull. 2000; 44: 363-370. doi: $10.1007 / \mathrm{s} 002890070085$.

8. Moravskyi VS, Levytskyi VYe, Masyuk AS, Khromiak UV. Influence of modified compacted expanded polystyrene on the rheological properties of polyamide 6 and polystyrene. Voprosy Khimii i Khimicheskoi Tekhnologii. 2019; (1): 35-41. doi: 10.32434/0321-4095-2019-122-1-35-41.

9. Mittal V. Functional polymer blends: synthesis, properties, and performance. Boca Raton: CRC Press; 2012. 342 p.

10. Thakur VK, Thakur MK, Pappu A. Hybrid polymer composite materials: properties and characterization. Cambridge: Woodhead Publishing \& Elsevier; 2017. 430 p.

11. Krigbaum WR, Wall FT. Viscosities of binary polymeric mixtures. J Polym Sci. 1950; 5: 505-514. doi: 10.1002/pol.1950.120050408.

12. Cragg LH, Bigelow CC. The viscosity slope constant k'-ternary systems: polymer-polymer-solvent. J Polym Sci. 1955; 16: 177-191. doi: 10.1002/pol.1955.120168208.

13. Unar IN, Soomro SA, Aziz S. Effect of various additives on the physical properties of polyvinylchloride resin. Pak J Anal Environ Chem. 2010; 11: 44-50.

14. Stuart B. Infrared spectroscopy: fundamentals and applications. New York: John Wiley \& Sons; 2004. 203 p. 